is quiet and most of the nest entrances are loosely plugged, only the occasional pushing up of dirt in some of the nests indicating that digging may be in progress. Marked nests were open for two or three days, except when they were plugged with loose dirt in the afternoon, and one nest was open at least five days. The nests were hard to keep track of during the period of observation because of frequent rains. By July 27 there were 55 nests in a marked area $4^{\prime} \times 4^{\prime}$ and there were at least this many active during the rest of the summer. Solenopsis ants raided part of the site but there was no sign of social or other parasites.

Individual nests were dug up but none could be excavated completely. The holes could be followed down to about 4", where they seemed to end in loose dirt; below some of them, at $5^{\prime \prime}$ to $6^{\prime \prime}$, a cluster of up to ten bruchids, with an egg or larva, indicated where the cell must have been. The cells must be of very loose construction. Nesting activity and male swarming continued from mid-July well into September in 1958, gradually diminishing during the latter month. A similar schedule has been maintained in the two succeeding years. No adults have been seen until July, the normal starting time of the summer monsoon season.

\title{
THE TYPE SPECIES OF THE ANT GENUS EURHO-
} $P A L O T H R I X$. - In our paper, "A world revision of the ant tribe Basicerotini," Studia Entomologica, Petrópolis, Brazil, 3: 202, I960, we erected a new genus Eurhopalothrix to receive certain species formerly placed in Rhopalothrix Mayr, along with some new species. Through inadvertance, no type species was cited for the new genus, and we therefore here designate Eurhopalothrix bolaui (=Rhopalothrix bolaui Mayr, I870) as type species of the genus Eurhopalothrix Brown and Kempf. - W. L. Brown, JR., Department of Entomology, Cornell University, Ithaca, N. Y., and W. W. Kempf, o. F. M., São Paulo, Brazil. 

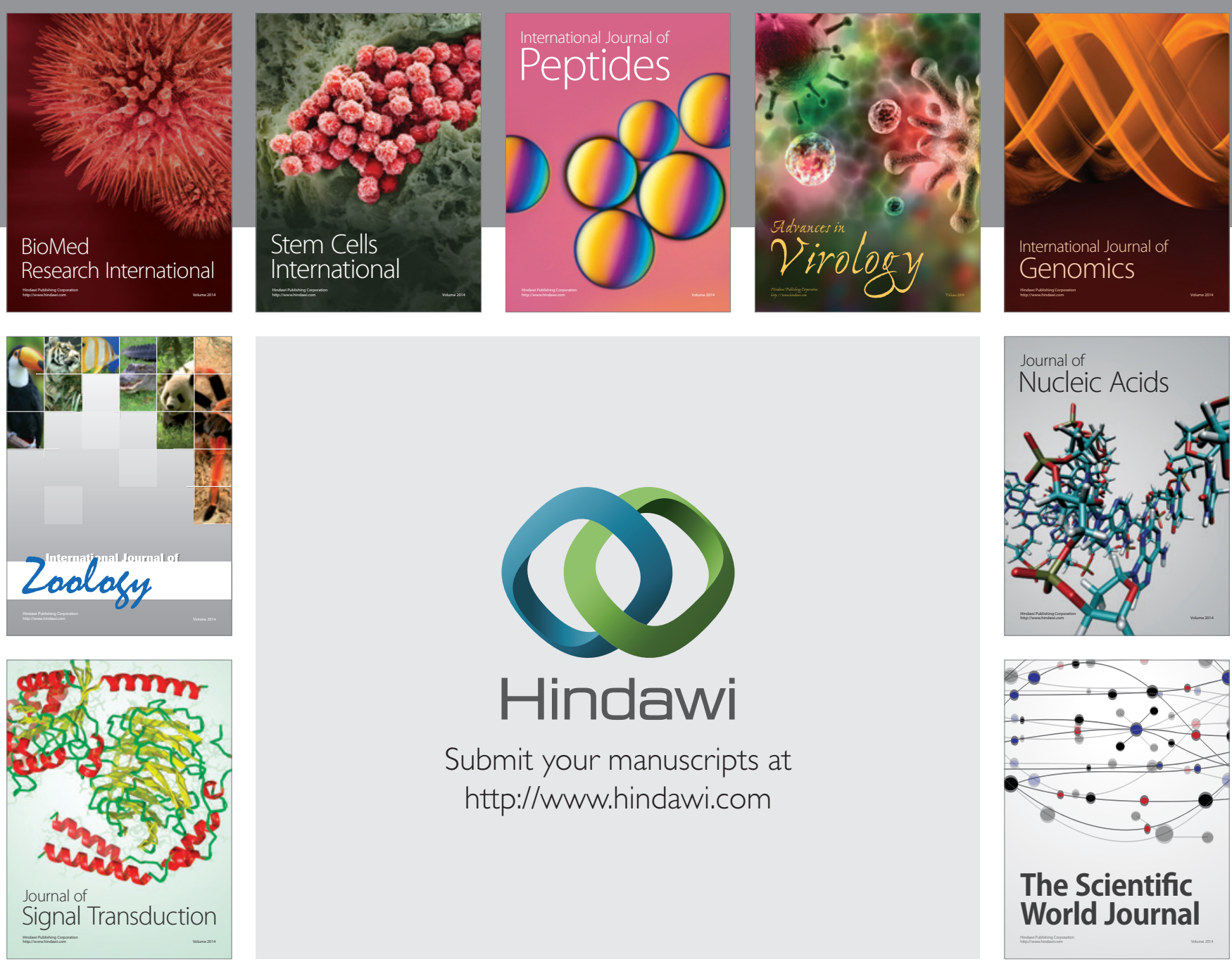

Submit your manuscripts at

http://www.hindawi.com
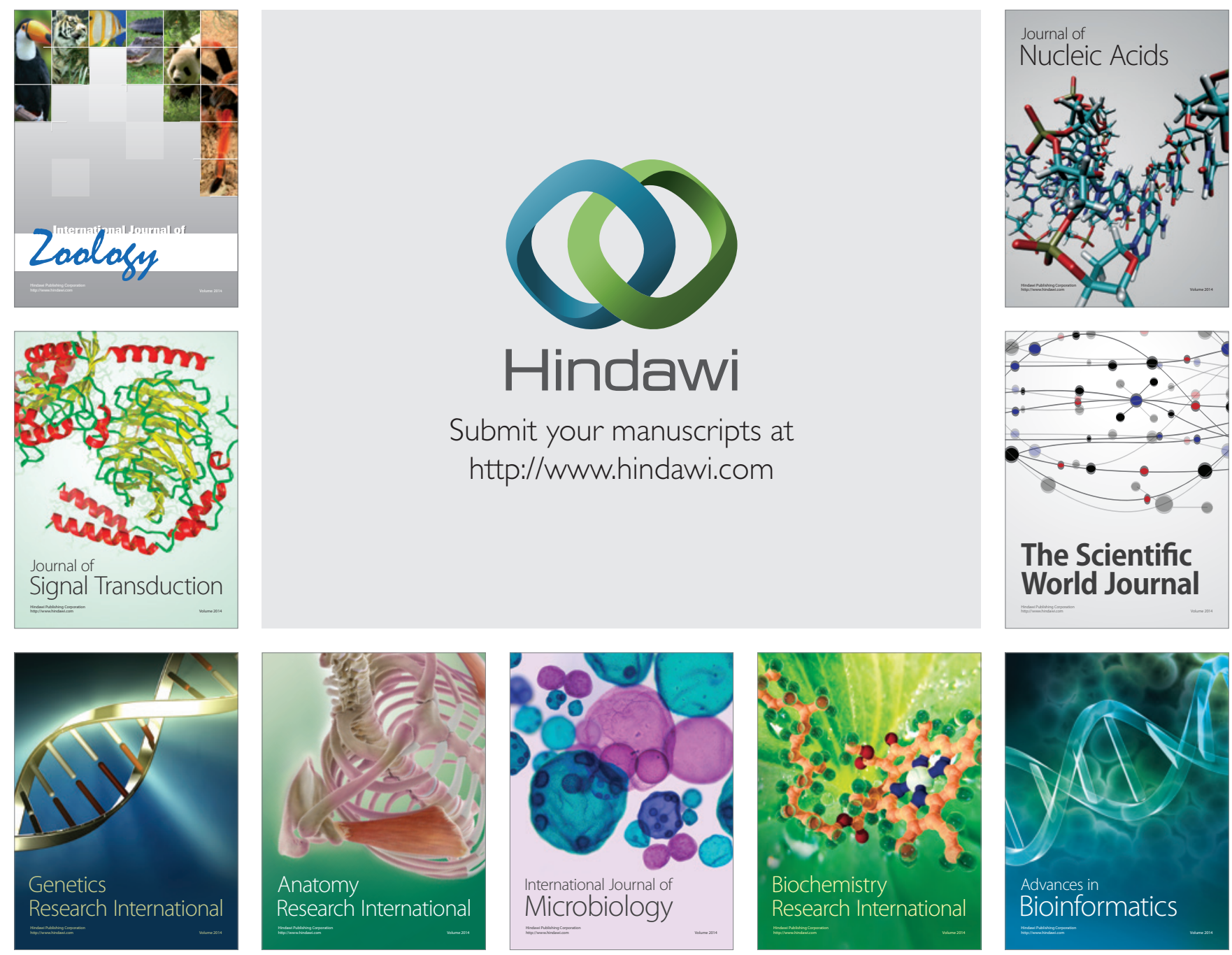

The Scientific World Journal
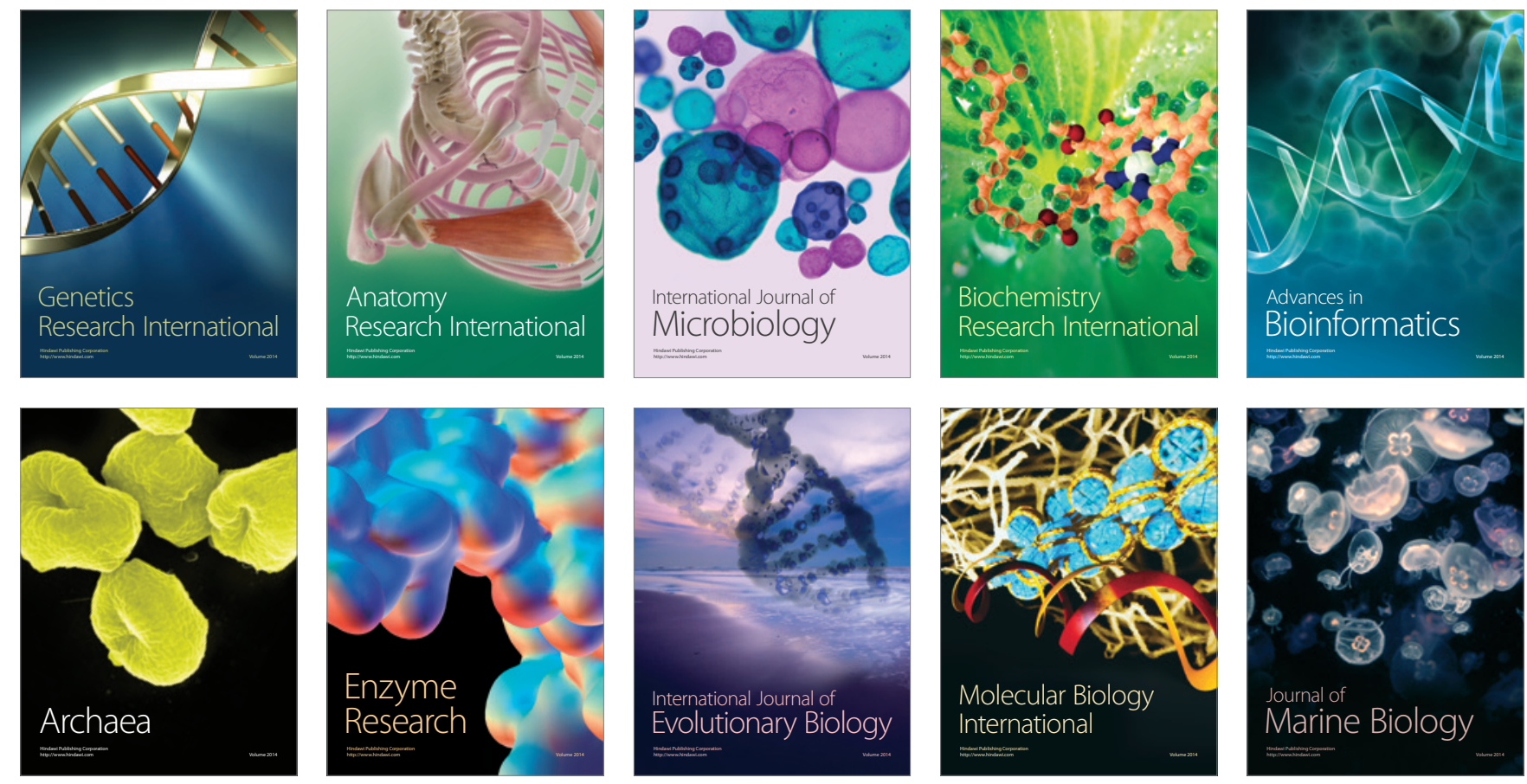